\title{
The Impact of the Blight Upon the Pre-Famine Rural Economy in Ireland
}

\author{
PATRICK McGREGOR* \\ Ulster Polytechnic
}

Abstract: The efficiency wage model is developed in this paper to explain the radical restructuring of agricultural production towards cattle and sheep in Ireland that occurred after the blight attack of 1846. The pre-Famine structure and production changes consequent to the blight are examined statistically using cross sectional data at a county level. The paper concludes that the blight led to an increase in the wage floor which prevented the labour market clearing and which favoured livestock production by those producers who remained. Substantial emigration forced landlords to absorb a significant proportion of the loss due to the blight.

\section{INTRODUCTION}

The blight which attacked the potato crop in 1845 and 1846 administered a profound shock to the Irish rural economy. Recent scholarship has revised upward the excess mortality of the period and as many as 1.1 million may have perished due to famine between 1846 and 1851 (see Mokyr, 1983, p. 266). The Famine led to a considerable change in the composition of Irish agricultural output with much greater emphasis being placed upon livestock and their associated products (O Gráda, 1978, p. 1a). The extent to which this confirmed an existing trend has been vigorously debated (see Crotty, 1966; Lee, 1969; Goldstrom, 1982).

The blight was the harbinger of the Great Famine, which dominated the demographic and agricultural history of nineteenth-century Ireland. This tended to obscure the remarkable impact the blight itself had upon Irish

*The author is lecturer in economics at the Ulster Polytchnic. He wishes to thank L.A. Clarkson, L. Kennedy, C. Chambers, P. Solar and two anonymous referres for comments on earlier drafts. 
agricultural output. Though the total value of livestock hardly changed in the period 1845-47, its composition altered radically with cattle numbers increasing by over 10 per cent. ${ }^{1}$ The corn acreage increased in many areas but never balanced the major reduction in the root acreage. ${ }^{2}$ Since livestock numbers were roughly constant, this suggests that there was a significant reduction in the labour input to agriculture because the potato crop was considerably more labour intensive than cereal crops (see Griffith, 1853, p. 28 and Barrington, 1886, p. 147).

The regional pattern of production changes over the blight period was diverse. Connaught, unlike the other provinces, witnessed a fall in cattle holding as well as the largest reduction in root acreage (82\%). Ulster and Leinster had similar falls in root acreage (about $60 \%$ ) but whereas cattle holding increased by 5 per cent in Leinster, in Ulster the increase was almiost five times this. Thus the year following the devastation of the potato crop in the autumn of 1846 witnessed a radical and varied restructuring of Irish agricultural production.

This paper seeks first to analyse the major movement from tillage to livestock production that followed the blight attack and then to employ the analysis to account for the extremely varied response of districts to the shock. The next section examines the principal characteristics of the preFamine rural economy and the role of the potato. This provides the basis for a model of the impact of the blight upon peasant income and production in 1846, which is developed in Section III. This model is employed in Section IV to explain the variations in production changes that occurred between counties. Finally, in Section V we present our conclusions.

\section{THE STRUCTURE OF AGRICULTURAL PRODUCTION IN THE; PRE-FAMINE ECONOMY}

The potato was the heart of the pre-Famine agricultural system. By its

1. Unfortunately the official agricultural statistics only begin in 1847 - prior to this the only comprehensive statistics of livestock are contained in the Tables of Rural Economy of the 1841 Census. Although 1840 was not a good year for agriculture, lack of alternative statistics forces us to take the 1841 figures as representative of the situation in 1845 . We thus compare the figure for total cattle in 1841 with that of cattle greater than one year old in 1847 since the Census excluded "calves of the current year". (See Bourke, 1965, pp. 301-302.) The figures for the root acreage come from a comparison of Mokyr's (1981) estimate of the potato acreage with the official 1847 return for the total ront and greens acreage. The pre-Famine turnip acreage is assumed to be negligible.

2. According to Bourke (1967, Appendix 4, pp. 1-7), the oat acreage increased from 2.5 million acres in 1845 to $3.0 \mathrm{~m}$ in 1846 , falling to 2.2 in 1847 . The corn acreage in Bailieborough Poor Law. Union (PLU) increased from 20,300 acres in 1845 to 24,800 in 1847 while potatoes, turnips and greeris fell from 12,300 to 3,400 . However, Bailieborough was a family farm type area and its county experienced a sharp increase in cattle numbers. 
destruction of the potato crop, the blight dealt the entire system a severe blow, the particular severity of which depended upon the importance of the potato in agricultural output. This varied considerably across regions and social classes. Since comprehensive output statistics do not exist for the preFamine period we are forced to measure local dependence upon the potato indirectly. In order to justify the measures chosen, we briefly examine agricultural production.

According to Ó Gráda's estimates, the potato on its own accounted for one-quarter of total agricultural output in 1840/45. Together with the other tillage items and their associated livestock (pigs and poultry), it accounted for over 80 per cent. The remainder was made up by cattle and sheep and their products (Ó Gráda, 1978, p. 1).

The potato was integral to the tillage system, though the system itself varied widely. The potato almost universally was cropped in rotation with cereals - its role was similar to the one played by the turnip in contemporary British agriculture. In a sample of 99 witnesses to the Devon Commission ${ }^{3}$ (one of the major sources of evidence concerning the pre-Famine rural economy) about one-third considered continuous cropping (with one or two cereal crops taken after the potato) to be the dominant technique of their locality. The rest of the witnesses observed that a ley system was employed - the cycle of tillage crops was broken and the land used for grazing for a period (McGregor, 1980, p. 70). The witnesses were clearly describing a spectrum of varying tillage intensity, which we may define as the proportion of output value represented by tillage crops. Soil conservation requires that the nutrients depleted by cropping should be replaced if fertility is to be maintained. The ley system employed the manure from grazing livestock, partly foddered with tillage products. Continuous cropping was particularly associated with manures drawn from the sea or bogs. The major cost involved was labour and thus increased tillage intensity can be considered a substitution of labour for livestock. Since for many peasants their labour' was their main, if not only, asset, the system was attractive. The result was that effort expended on gathering manure was prodigious. ${ }^{4}$

Tillage used labour intensively compared to grassland production. This

3. Report from Her Majesty's commissioners of inquiry into the state of the law and practice in respect to the occupation of land in Ireland.

4. Children collected horse droppings along the road and labourers' families would scour their surrounds for manure. See Report from Her Majesty's commissioners of inquiry into the state of the law and practice in respect to the occupation of land in Ireland, 855, Q.81;88, Q.9; $548, Q .42 ; 849, Q .60$; N.A., 1843, p. 38. Sea and bog manure, which were used extensively, were especially important since they were not related to livestock. Seaweed in particular tended to be transported for considerable distances inland, with over $\mathbf{3 0}$ miles not being exceptional. (Manuring and cropping practice generally are examined in detail in McGregor, 1980, pp. 69-86). 
reflected the relative supply of factors, since labour was plentiful compared to land. As a consequence the wage rate was low - according to Bowley's investigations the wage rate in Irish agriculture was less than half that of the English average. ${ }^{5}$ High manuring rates were a major avenue by which the labour input into agricultural production was increased. Tillage yields were consequently high - higher in fact than in the post-Famine years (see Barrington, 1921). Since manure application could be easily varied this also serves to highlight the ease with which substitution occurred between latiour and land.

Subtenancy agreements reinforced this form of factor substitution. Potatoes had a low value to weight ratio and were thus not an attractive crop to market given the high transport costs of the pre-Famine period. The potato, however, was the mainstay of the Irish labourers' diet. By cottiering, free cropping and conacre ${ }^{6}$ a labourer could gain access to a tenant's land to grow potatoes, in return for labour or rent. The tenant had the benefit of a potato crop without any problems of marketing. Since these agreements were virtually universal (according to Bourke, 1959, p. 7, 14 per cent of all potato land was held in conacre alone) almost all households in the rural economy grew their own potatoes.

Pre-Famine agricultural production was dominated by tillage. The pattern, however, varied considerably from the continuously cropped small holdings on the seaboard, to the large, mixed dairy and tillage farms, on the richer soils. Our analysis suggests that increased tillage intensity was a substitution of labour for livestock. The correlation coefficients presented in Table 1 support this interpretation. Tillage intensity is measured inversely by the amount of livestock per worker, LIVAL/LABOUR and livestock per acre of potatoes, LIVAL/POTATO. The latter variable also serves as a measure of dependence upon the potato since it provides an indication of the relative importance of potatoes in output. ${ }^{7}$ LIVAL/LABOUR and LIVAL/POTATO

5. Bowley, 1898 , p. 706 and 1899 , p. 400.

6. Cottiering was essentially an exchange of land and labour. A labourer undertook to work for a farmer at a nominal wage and in return gained access to a house and some of the farmer's land for cropping, grazing and turbary. Such rights were given a nominal value against which was set, at the end of the year, the value of the labourer's earnings. The only money that changed hands was the difference between the two amounts.

Free cropping entailed a farmer giving land rent free to a labourer in exchange for manure which the labourer and his family had gathered throughout the previous year. Conacre was the letting of land for a season, generally for a money rent. The land was manured or capable of producing a crop without manure. These forms of subtenancy are examined in greater detail in McGregor (1980, pp. 117-121).

7. The proportion of land under potatoes does not provide a useful indicator of potato dependency due to difficulties in adjusting for land quality and the resulting ambiguity concerning the relative proportion of potatoes in output. 
Table 1: Correlation coefficients between county production characteristics in the pre-Famine rural economy

\begin{tabular}{lcccc}
\hline \hline & LABLAND & LIVAL/LABOUR & LIVAL/POTATO & MEAN \\
\hline LABLAND & & & & \\
LIVAL/LABOUR & $-0.54^{* *}$ & & & \\
LIVAL/POTATO & $-0.42^{* *}$ & $0.78^{* *}$ & & \\
MEAN & $-0.37^{*}$ & $0.68^{* *}$ & $0.53^{* *}$ & \\
LIVAL 1-15 & $0.71^{* *}$ & $-0.63^{* *}$ & $-0.45^{* *}$ & $-0.81^{* *}$ \\
\hline \hline
\end{tabular}

Significance: $* *$ indicates the coefficient is significant at the $1 \%$ level

* indicates the coefficient is significant at the $5 \%$ level

Notes: (1) LABLAND is LABOUR/LANDVAL where LABOUR is the number of agricultural workers 8 and LANDVAL a measure of effective land input to agriculture. 9

(2) LIVAL is the aggregate value of livestock according to the 1841 Census with LIVAL $1-15$ being the proportion of this on farms between 1 and 15 acres.

(3) POTATO is the acreage estimate made by Mokyr (1981).

(4) MEAN is an estimate of average holding size.10

are strongly correlated with each other and both are negatively correlated with the labour-land ratio, LABLAND.

The continuous cropping regime was extremely labour intensive. The managerial difficulties inherent in supervision made it particularly suited to small holdings. Table 1 also indicates that tillage intensity varied inversely with average holding size, MEAN, and the proportion of livestock held on holdings of 1.15 acres. Thus, areas which were particularly vulnerable to the blight were those where small holdings proliferated. The blow caused by the blight was to fall hardest upon those least able to bear it.

8. The 1841 Census figures of the total number of persons above 15 years in the categories farmers, servants and labourers, ploughmen, gardeners, graziers and herds was used.

9. The Townland Valuation was employed to measure effective land input. The total valuation is broken down between land and property for nine counties in a parliamentary return (British Parliamentary Papers, 1840). A log linear regression of land value on total value and LABOUR was run and used to estimate LANDVAL for the remaining counties covered by the Townland Valuation. This left six counties for which the Tenement Valuation was employed, adjusted for land (see McGregor, 1980 , p. 107) and standardised to the Townland Valuation level (see Report from the select committee on general valuation, Appendix No. 8, British Parliamentary Papers, 1868-69).

10. A parliamentary return (British Parliamentary Papers, 1845) gives the number of holdings broken down into 21 divisions. These, however, are on a poor law union basis and were aggregated into counties. When a union encompassed more than one county, the holding data was distributed between the counties using as weights the relative number of tenements. These data are given in Returns of parliamentary electors (British Parliamentary Papers, 1844). 


\section{THE IMPACT OF THE BLIGHT IN 1846}

In this section we present a model of the blight's impact upon the rural economy. We first state the assumptions used in the analysis and discuss the nature of the shocks administered in the autumn of 1846 . The reaction of the rural economy is then deduced.

First consider production. This occurs with a lag - material inputs are combined with two factors, land and labour, at the beginning of the cycle, and output is produced after one year. There is no capital market and thus each producer or peasant is constrained by his current income. Wages are paid at the beginning of production and rents at the completion of the cycle. The peasant's consumption is a simple function of his income, defined as the value of his outputs plus net wages received minus rent due to the landlord at the end of the cycle. Thus a labourer not involved in production on this own account would have an income equal to his wages. Consumption is the first call on income and the remainder comprises the peasant's investment his outlay on inputs and non-domestic labour.

Turning to the aggregate economy, we assume that labour is plentiful relative to land (which is entirely owned by an unproductive landlord class distinct from the peasants). The wage level, consequently, is low - just above the efficiency floor. The concept of an efficiency floor to the wage rate is fundamental to our interpretation of the response of the rural economy to the shocks it received in 1846. It is thus necessary to examine the hypothesis briefly.

The essential point of the hypothesis concerns the connection between work efficiency and nutrition when the latter is at a low level (see Mazumdar, 1959). A distinction is made between the time worked by the labourer and the work units supplied. At very low wage levels (and thus at low nutritional levels) it is asserted that the supply of work units per laboures: is elastic with respect to the wage rate, i.e., the number of work units supplied by the worker increases more than in proportion to the increase in the wage rate. As long as this happens the wage cost per unit falls with increased wages. A floor exists to the wage rate corresponding to the lowest average cost per work unit supplied per man. This can be seen clearly if we assume that the labourer's supply of work units per hour, $\mathrm{N}$, is a function of his real wage per hour, $W / P$, i.e.,

$$
\mathrm{N}=\mathrm{N}(\mathrm{W} / \mathrm{P})
$$

where $\mathrm{W}$ is the money wage and $\mathrm{P}$ an index of the cost of living. The cost of a work unit, $C$ is then $W / N$. The employer will seek to minimise this by suitable choice of $\mathrm{W}$. This occurs when 


$$
\partial \mathrm{C} / \partial \mathrm{W}=\left(\frac{\mathrm{W}^{*} / \mathrm{P}}{\mathrm{N}}\right) \cdot \mathrm{N}_{\mathrm{W} / \mathrm{P}}-1=0
$$

(writing $N_{W / P}$ for $\partial N / \partial \frac{W}{P}$, etc., and assuming $N_{\frac{W}{P}} \frac{W}{P}<0$ ). Note that $W^{*} / N$ is the minimum price of labour - if $\mathrm{W}$ is reduced below $\mathrm{W}^{*}$ then $\mathrm{C}$ actually increases since the drop in the labourer's physical capacity is proportionately greater than the saving in wages. The supply of labour units is zero below $\mathrm{W}^{*} / \mathrm{N}$ (for more detailed examination of this model see Mirrlees, 1975, p. 87).

The resulting aggregate supply schedule for labour is depicted in Diagram 1 by $\mathrm{S}$. It is infinitely elastic at the efficiency floor as long as there is some labour unemployed. Beyond this point the supply schedule becomes a conventional upward sloping one. Diagram 1 is drawn with the equilibrium initially at $\mathrm{W}_{0}$, above the floor rate of $\mathrm{W}_{0}^{\mathrm{F}}$. (Recent historical research ${ }^{11}$ would suggest this is a reasonable assumption for the pre-Famine rural economy.)

Diagram 1: The impact of the blight on the labour market

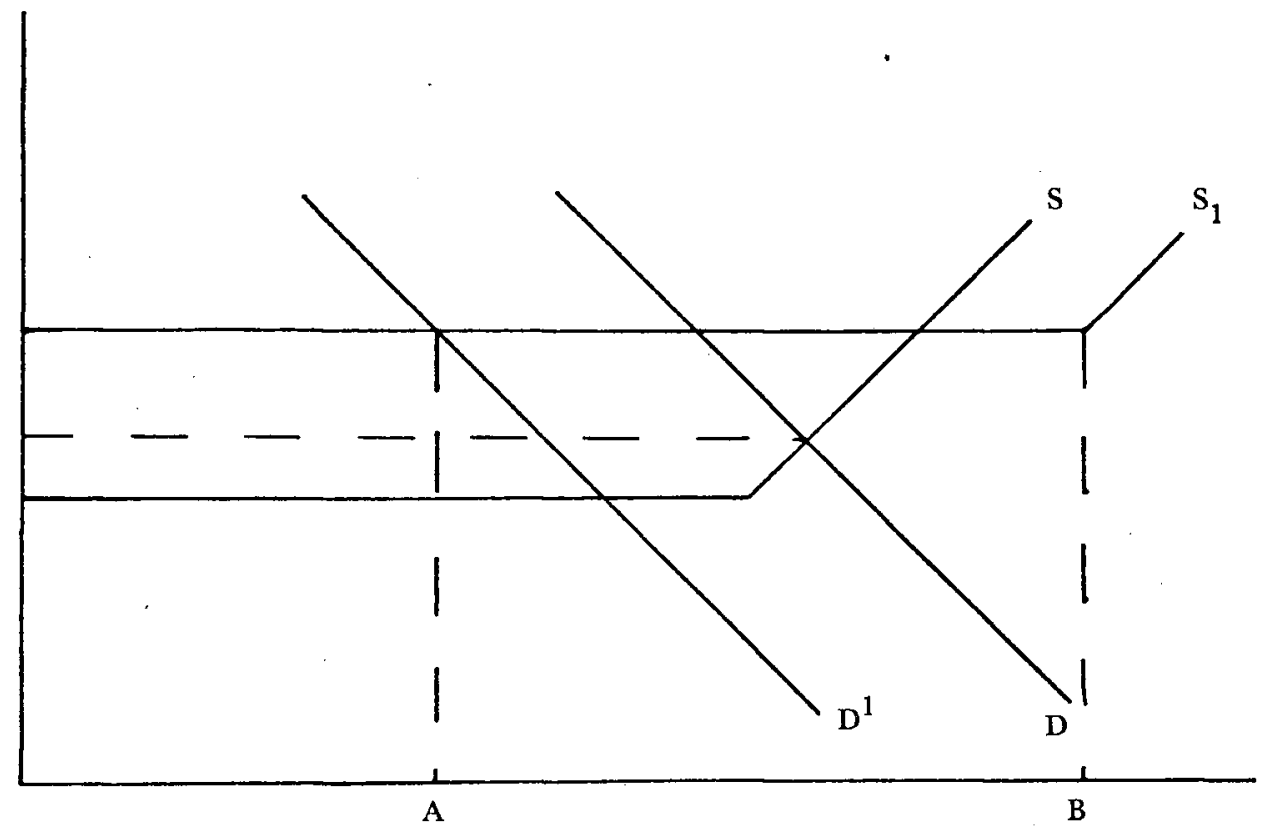

WORK UNITS

11. See Mokyr, 1983, pp. 7-8. Crawford's (1978) analysis of workhouse diets concludes (pp. 89-91) they were nutritionally adequate and thus it is likely that the labourers' diets in the rural economy were likewise. 
We return to the model of the rural economy. Since substitution between land and labour is easy, the low wage rate leads to production being labour intensive. There is wide access to land and all peasants are producers. We may divide the peasants into three classes - (i) labourers and small holders whose production is limited - for many it would be restricted to groving potatoes, the staple foodstuff; (ii) family farmers wholly employed on their own holdings and who demand labour only at seasonal peaks; and (iii) commercial farmers who are regular employers of labour. The economy is assumed to be small and open, with product prices determined in the world market, except for the potato whose bulk and low value means that it is not traded widely. It is further assumed that the role of the potato decreases as the scale of production increases. In order to simplify the analysis we assume that the blight destroys the entire potato crop. (In reality it destroyed 80 per cent - see Bourke, 1959, p. 11.) The assumption of total destruction in our subsequent analysis does not.alter the logic of the model, though it means that the price of potatoes is irrelevant and this is a useful simplification. The only domestically determined prices are thus those of the factors of production.

The rural economy is assumed to be in static equilibrium when it is subjected to two simultaneous shocks. First, the potato crop fails completely, and second, world food prices increase sharply due to widespread crop failure. ${ }^{12}$ Let us consider the effects of these shocks upon peasants' curient income, defined as the value of outputs plus net wages minus rent due. We will assume initially that the rent level is unchanged. Since wages are paid at the beginning of the cycle only output value will be affected by the shacks and the magnitude and direction of the change on peasants' incomes will depend upon the proportion of potatoes in output value in the equilibrium situation. Since we have assumed that this proportion declines with the scale of production, it is clear that the greatest loss will be suffered by the labourers whereas the commercial farmers would be net beneficiaries in nominal terms. The effect on family farmers is ambiguous, but it seems likely that, given the importance of the potato crop in their total production, they would probably suffer a net loss of income.

We now examine the impact of the shocks upon the wage rate. The loss of the potato crop will mean that other foodstuffs will now be consumed. Their

12. This is what occurred in $1846-47$. The harvest of 1846 was poor throughout Europe due to deficient corn crops as well as the potato blight. The average price of wheat in England and Wales rose from $57 \mathrm{~s}$ per quarter in the three months to 28 th November, 1846 , to $81 \mathrm{~s}$ in the same period to 29 th May, 1847 (see Tooke, 1840, pp. 28-29 and also Gayer, et al., 1975, p. 508). In the US the price of wheat flour rose from $\$ 5.06$ per $100 \mathrm{lbs}$ in 1846 to $\$ 6.69$ in the following year. (See US Department of Commerce, 1975, p. 209. Irish prices are given in Barrington, 1927, p. 251.) Thus 1847 was a year of high food prices internationally. 
prices, however, have sharply increased. The effect on the efficiency floor of an increase in the price level can be seen by totally differentiating (1) which gives

$$
\mathrm{dW}^{*} / \mathrm{W}=\mathrm{dP} / \mathrm{P}
$$

i.e., employers would be behaving rationally by increasing money wages in the same proportion as prices - the real wage rate that minimises the cost of labour is invariant to changes in the cost of living. In Diagram 1 this is illustrated by the upward shift in the supply schedule from $S$ to $S_{1}$. The loss of the potato crop will lead many producers to seek more employment than in the previous year from the labour market. The horizontal part of the schedule for $S_{1}$ is thus longer than for $S$. The original wage rate, $W_{0}$, was assumed slightly above the floor level of $W_{0}^{F}$. Given that food prices have risen substantially we have drawn the new floor wage, $W_{1}^{F}$, significantly above $W_{0} .{ }^{13}$ Since we have assumed the rent level to be unchanged this will lead to an increase in the relative price of labour.

Let us now turn to the anticipated income of each class in the following year. The labourer's income will consist of the wages received from any employment he is able to secure. The commercial farmers will face higher prices for their inputs and consumption, but since their nominal income has also increased their real income is probably not greatly affected. With regard to the future, producers will respond to the increase in the price of labour relative to land. Technique would tend to be less labour intensive and the output mix could be altered favouring those products which used land more intensively. Assuming that prices were expected to return to normal the anticipated income of the commercial farmers is unlikely to be greatly affected by the potato failure and the change in the price level.

The family farmers would be in a much less favourable position as their real income has definitely fallen. Since consumption would now take a greater proportion of their income, their outlays would be cut back and thus their anticipated income would fall. Their demand for labour would drop, shifting the aggregate demand curve in Diagram 1 to the left. Production would respond to the increased relative price of labour. Their income now could be crucially dependent upon wages gained from employment.

If we now introduce emigration as an alternative option for producers, it is reasonable to consider that propensity to emigrate is a function of the proportional fall in anticipated future income, given that the individual has sufficient resources. Our model has the fall in anticipated income graduated from commercial farmers who were unaffected to labourers who were

13. Using a post-Famine study of labourers' diets we find that the index of the cost of living (with $1853=100$ ) in 1847 was 171 (see McGregor, 1980, p. 228). 
devastated. The family farmers and the producers below them who have sufficient resources have the highest propensity to emigrate since their anticipated income has been hardest hit. The smaller commercial farmers would be affected in a similar though less dramatic way.

The introduction of emigration affects Diagram 1 in two ways. First, many smaller tenants whose survival would depend on gaining employment would probably prefer to emigrate, reducing the horizontal portion of $\mathrm{S}_{1}$. Second, emigration of family farmers and those above them would reduce demand for labour, shifting $\mathbf{D}$ further to the left.

Now let us allow the land market to respond competitively to the blight situation. The rent level for the coming year would also likely fall since between the destitution of many small producers and the emigration of many more substantial ones, the aggregate demand for land would fall. However, such a fall in the rent level would exacerbate the excess supply in the labour market as it would increase the relative price of labour.

In conclusion, the model we have constructed suggests the following interpretation of developments in the autumn of 1846. The rural economy suffered two shocks. The blight destroyed a substantial part of the resources of the poorer producers, leading to an increase in the supply of labour. Demand for labour dropped due to the major reduction in the anticipated income of many producers who had the resources to emigrate. The simultaneous increase in world food prices led to the efficiency wage floor being raised. The effect of these developments was to lead to chronic excess supply in the labour market, given by $\mathrm{AB}$ in Diagram 1. The unemployed were dependent on the Government relief schemes or private charity. The peasants who continued production responded to the increase in the relative price of labour by developing livestock production.

\section{AGRICULTURAL PRODUCTION 1845-47}

The production changes over the blight period reflected the outcome of two distinct processes. The first of these was the withdrawal of many peasants from production because the blight had robbed them of their resources or had so reduced them that they preferred to emigrate. (See McDonagh, 1956, p. 388 for the extent of this.) The other process consisted of the restructuring of the output of those peasants who remained in response to the change in costs which accompanied the potato failure. The most radical restructuring would have been required for those who formerly had been heavily involved in tillage. Thus, we would expect that the aggregate production changes would reflect how resources were distributed in the pre-Famine period.

Several aspects of this are examined statistically in Table 2. The percentage change in cattle numbers 1845-47, CATCHANGE, and the root acreage, 
ROOTCHANGE, together with the percentage of excess land in 1847, EXCESSLAND, ${ }^{14}$ are correlated with the proportion of total livestock value held on various holding divisions; LIVAL $1-5$ being the proportion of total livestock value in 1841 held on holdings of 1 to 5 acres, etc. Because of ambiguities in the census concerning the acreage unit between Ulster and the remaining provinces the sample has been restricted to Leinster, Munster and Connaught.

Table 2: Correlation between production changes $1845-47$ and pre-blight livestock holdings

\begin{tabular}{lcccc}
\hline \hline & LIVAL1-5 & LIVAL5-15 & LIVAL15-30 & LIVAL' 30 \\
\hline CATCHANGE & $-0.556^{* *}$ & -0.201 & $+0.495^{* *}$ & 0.295 \\
ROOTCHANGE & $-0.626^{* *}$ & $-0.645^{* *}$ & -0.019 & $0.754^{* *}$ \\
EXCESSLAND & $0.528^{* *}$ & 0.118 & -0.309 & -0.319 \\
\hline
\end{tabular}

The signs of the significant coefficients are as expected. The results illustrate the destruction of the small holders, especially in the 1 to 5 acre category, with areas where their proportion was high experiencing large falls in root acreage and small increases in cattle numbers, together with high excess land. Connaught's dilemma can be judged from the fact that whereas just over one-fifth of the total livestock for the southern three provinces was held on holdings under 5 acres, in Connaught the proportion was almost double this.

In the next holding category, of 5-15 acres, we would expect to have a high propensity to emigrate. The average value of their pre-Famine livestock holding was over $£ 23$ which, against passage costs to North America of £3-5 per person, meant they had the resources. The negative correlation with the root change indicates the relative lack of productive activity from this category, compared to the large holdings. As expected, the 15-30 acre category is positively associated with the increase in cattle numbers.

The change in cattle numbers was regressed upon a number of variables measuring the distribution of holdings. The proportion of holdings between 10 and 50 acres gave the best result. This would represent the peasant class that most actively expanded livestock production. The other explanatory variable employed was land quality. As expected, better quality land favoured

14. EXCESSLAND was formed by taking the crop and grass acreage in the 1851 Census and deducting first the 1847 crop acreage and then the grass required for the 1847 stock, using the stocking rates of 1858 , which were assumed to be at an equilibrium level. 
the expansion of cattle holding. Ordinary least squares regression gives the following equation: (variables are in natural logs; figures in parentheses are $t$ ratios).

$$
\text { CATCHANGE }=0.50+0.37 * * \text { HOLD } 10-50+0.09 * * \text { LANDQUAL }
$$

$$
\mathrm{R}^{2}=0.38 \quad \mathrm{~F}=8.93 \quad \mathrm{~N}=32
$$

Where: CATCHANGE $=1847$ cattle numbers as a ratio of the 1841 figure. HOLD10-50 = proportion of total holdings between 10 and 50 acres.

LANDQUAL = land quality, LANDVAL/AREA.

The excess land variable warrants some further discussion since, according to our calculation, it amounts to over a fifth of the 1851 crop and grass acreage and this, even allowing for some inaccuracy, must have led to a drop in the aggregate rent paid. In addition, the proportion of excess land in a region would exert a pressure on the rent level. There is some evidence of rent rebates and also of resistance to payment. According to $O$ Gráda's estimates, head rents fell from $£ 12 \mathrm{~m}$ in $1840 / 45$ to $£ 10 \mathrm{~m}$ in 1854 , though Donnelly's examination of Cork rentals indicates 1849 as the year when major rebates were granted. However, Donnelly is dealing with head renits and admits that many middlemen - substantial lease holders who sublet their land - were squeezed out and this would likely have led to a lower rent being paid by the farmer. (See Ó Gráda, 1978, p. 4; McGregor, 1980, pp. 200-201; Donnelly, 1975, pp. 200-207.) A fall in the future rent level would have encouraged some peasants to stay in production though it would also have increased the relative price of labour.

If the land market operated perfectly, we would have expected the rent level to have been bid down until most land was in production. Many factors prevented such an adjustment. The land market was not perfectly competitive but made up of many local markets loosely joined together. The local markets would have been affected in radically different ways. When small holdings dominated, as on the western seaboard, the rural economy was devastated by the blight. There would have been insufficient peasants with the resources necessary to stock the land - even if this was given rent free. (See the comments of Locke, 1852, concerning its quality.)

In addition to these considerations, the rent would have to cover the fixed costs of letting and rates. The latter point is especially important since the immediate lessor paid the rate on all property valued at less than $£ 4$. (There 
was no immediate rate on vacant property.) Local taxation did not start to climb steeply until 1848, though it is likely that peasants and landlords anticipated this. This would have increased the minimum economic rent, making it cheaper to leave some land vacant. The major drop in rent payments over the period effectively paralysed much estate management. Inevitably, those who received rents would have had to absorb a significant part of the fall in output value due to the blight. Not to have done so would have forced more peasants to emigrate and consequently to have reduced future rentals. As it was, the Famine set in motion a major restructuring of land ownership.

\section{$\mathrm{V}$ CONCLUSION}

The blight attacked a rural economy characterised by wide access to land and a low wage rate. It shattered both aspects. The poorer strata, who gained access to land on the basis of intensive potato cultivation, were robbed of much of their output by the blight and forced to consume the resources required for future production. In addition, the higher wage rate consequent to the blight favoured the production of livestock and deprived the poor of their resort to the labour market, then characterised by chronic excess supply.

On the other hand, the large farmers were not greatly affected since their output was made up to a much greater extent of livestock and cereals. However, between the two extremes lay many family farms. The blight led to a serious reduction in their output, though this would have been partially compensated by high world prices for agricultural products. Since they had sufficient resources to emigrate, there was a level of anticipated income from production below which the emigration option would be exercised. The ability of large sections of the population to emigrate, together with the devastation of the small holder and cottier, exerted a downward pressure on rents. As a result landlords as a whole were forced to absorb a significant proportion of the loss of income, though the extent of their loss would be determined by the composition of their lettings.

\section{REFERENCES}

BARRINGTON, R.M., 1886. "The Prices of Some Agricultural Produce and the Cost of Farm Labour for the Past Fifty Years", Journal of the Statistical and Social Inquiry Society of Ireland, Vol. IX, pp. 137-153.

BARRINGTON, T., 1921. "The Yields of Irish Tillage Food Crops since the Year 1847", Department of Agriculture and Technical Instruction for Ireland, Journal, Vol. 21, No. 2, pp. 205-229; No. 3, pp. 289-305.

BARRINGTON, T., 1927. "A Review of Irish Agricultural Prices", Journal of the Statistical and Social Inquiry Society of Ireland, Vol. XV, pp. 249-280. 
BOURKE, P.M.A., 1959. "The Extent of the Potato Crop in Ireland at the Time of the Famine", Journal of the Statistical and Social Inquiry Society of Ireland, Vol. XX, Part III, pp. 1-26.

BOURKE, P.M.A., 1965. "The Agricultural Statistics of the 1841 Census of Ireland: A Critical Review", Economic History Review, second series, Vol. XVIII, No. 2, pP. 376-391.

BOURKE, P.M.A., 1967. "The Potato, Blight, Weather, and the Irish Famine", unputlished $\mathrm{PhD}$ thesis, University College Cork.

BOWLEY, A.L., 1898-99. "The Statistics of Wages in the United Kingdom during the Last Hundred Years", Part I, Agricultural wages; Part III, Agricultural Wages - Ireland, Journal of the Royal Statistical Society, 1898, pp. 702-722; 1899, pp. 395-404.

British Parliamentary Papers, 1840. An abstract, arranged according to baronies, of the valuation of the lands and houses of the several parishes in each of the counties, counties of cities, and counties of towns which have been surveyed and valued in pursuance of the Act 7 Geo IV, c.62, Vol. 48.

British Parliamentary Papers, 1843. Report of the commissioners appointed to take the census of Ireland, for the year 1841 , Vol. XXIV.

British Parliamentary Papers, 1844. Returns of parliamentary electors; also of tenements valued under the Act 1\&2 Vic cap.56, for relief of the poor in Ireland, Vol. 43.

British Parliamentary Papers, 1845. Report from Her Majesty's commissioners of inquiry in to the state of the law and practice in respect to the occupation of land in Ireland, Vols. XIX-XXII.

British Parliamentary Papers, 1847. Summary of the results of the experiment tried under the direction of the Lords of the Committee of Privy Council, in 1845 and 1846, to obtain agricultural statistics in the union of Hartley Wintney in England, the county of Edinburgh in Scotland, and Bailieborough Union in Ireland, Vol. LIX.

British Parliamentary Papers, 1847-48. Returns of agricultural produce in Ireland in the year 1847, Vol. LVII.

British Parliamentary Papers, 1849. Reports from the select committee on poor laws (Ireland), Vol. XV.

British Parliamentary Papers, 1852. Report from the select committee of the House of Lords on the Treasury minute, providing for the debts due from counties and union:s in Ireland by the imposition of a consolidated annuity, Vol. VI.

British Parliamentary Papers, 1864. Sixth report of the medical officer of the Privy Council, 1863, Vol. XXVIII.

British Parliamentary Papers, 1868-69. Report from the select committee on general valuation, Ireland, Vol. IX.

CRAWFORD, E.M., 1978. "A Nutritional Analysis of Diets in Ireland's Workhouse: 1841-1869", QUB dissertation.

CROTTY, R.D., 1966. Irish Agricultural Production: its Volume and Structure, Cork: Cork University Press.

DONNELLY, J.S., 1975. The Land and People of Nineteenth Century Cork: The Rural Economy and the Land Question, London: Routledge and Kegan Paul.

GAYER, A.D., W.W. ROSTOW and A.J. SCHWARTZ, 1975. The Growth and Fluctuation of the British Economy 1790-1850: An Historical, Statistical and Theoretical Study of Britain's Economic Development, Oxford: Clarendon Press.

GOLDSTROM, J.M., 1982. "Irish Agriculture and the Great Famine" in J.M. Goldstrom and L.A. Clarkson (eds.), Irish Population, Economy and Society: Essays in Honour of K.H. Connell, Oxford: Clarendon Press. 
GRIF FITH, J.R., 1853. General Valuation of Ireland: Instructions to Valuators and Surveyors, Dublin.

LEE, J., 1969. "Irish Agriculture”, Agricultural History Review, Vol. 17.

LOCKE, J., 1852. "Additional Observations on the Valuation and Purchase of Land in Ireland", Journal of the Statistical Society of London, Vol. XV, December, pp. 345350.

MAZUMDAR, D., 1959. "The Marginal Productivity Theory of Wages and Disguised Unemployed", The Review of Economic Studies, Vol. XXVI, No. 3, pp. 190-197.

MacDONAGH, O., 1956. "The Irish Emigration to the United States of America and the British Colonies during the Famine", in R.D. Edwards and T.D. Williams (eds.), The Great Famine: Studies in Irish History 1845-52, Dublin: Browne and Nolan.

McGREGOR, P.P.L., 1980. "The Irish Rural Economy, 1844-54: A General Equilibrium Approach to Famine, Relief and Change", unpublished $\mathrm{PhD}$ thesis, Edinburgh University.

MIRRLEES, J.A., 1975. "A Pure Theory of Underdeveloped Economies", in L.G. Reynolds, (ed.), Agriculture in Development Theory, New Haven: Yale University Press.

MOKYR, J., 1981. "Irish History with the Potato", Irish Economic and Social History, Vol. VIII, pp. 8-29.

MOKYR, J., 1983. Why Ireland Starved: A Quantitative and Analytic History of the Irish Economy 1800-1850, London: Allen and Unwin.

N.A., 1843. The South of Ireland and Her Poor, London.

Ó GRÁDA, C., 1978. "On Some Aspects of Productivity Change in Irish Agriculture 1845-1926", Paper prepared for Agricultural History Session, Section C, Seventh International Economic History Congress, Edinburgh.

TOOKE, T., 1840. A History of Prices, Vol. IV, London: Longman.

US DEPARTMENT OF COMMERCE, 1975. Historical Statistics of the United States, Colonial Times to 1970, Part $I$. 